\title{
Comparative Pathogenicity and Virulence of Fusarium Species on Sugar Beet
}

Pragyan Burlakoti, V. Rivera, and G. A. Secor, Department of Plant Pathology, North Dakota State University, Fargo 58105; A. Qi, Broom's Barn Research Center, Higham, Bury St. Edmunds, Suffolk, IP28 6 NP, England; L. E. Del Rio-Mendoza, Department of Plant Pathology, North Dakota State University; and Mohamed F. R. Khan, Department of Plant Pathology, North Dakota State University, and University of Minnesota

\begin{abstract}
Burlakoti, P., Rivera, V., Secor, G. A., Qi, A., Del Rio-Mendoza, L. E., and Khan, M. F. R. 2012. Comparative pathogenicity and virulence of Fusarium species on sugar beet. Plant Dis. 96:1291-1296.

In all, 98 isolates of three Fusarium spp. (18 Fusarium oxysporum, 30 F. graminearum, and 50 Fusarium sp. nov.) obtained from sugar beet in Minnesota were characterized for pathogenicity and virulence on sugar beet in the greenhouse by a bare-root inoculation method. Among the 98 isolates tested, $80 \%$ of isolates were pathogenic: $83 \%$ of the $F$. oxysporum isolates, $57 \%$ of the $F$. graminearum isolates, and $92 \%$ of the Fusarium sp. nov. isolates. Symptoms varied from slight to moderate wilting of the foliage, interveinal chlorosis and necrosis, and vascular discoloration of the taproot without any external root symp-

$12 \%$ were moderately virulent. Most of the highly virulent isolates (91\%) and moderately virulent isolates (89\%) were Fusarium sp. nov. All pathogenic isolates of $F$. graminearum and most pathogenic isolates $(87 \%)$ of $F$. oxysporum were less virulent. In general, more-virulent isolates induced first foliar symptoms earlier compared with lessvirulent isolates. This study indicates that both $F$. oxysporum and Fusarium sp. nov. should be used in greenhouse and be present in field studies used for screening and developing sugar beet cultivars resistant to Fusarium yellows complex for Minnesota and North Dakota.
\end{abstract} toms. Among the pathogenic isolates, $14 \%$ were highly virulent and
Minnesota and North Dakota produce more than $50 \%$ of the sugar beet (Beta vulgaris L.) in the United States (15). The sugar beet industry in the bi-state area contributes over $\$ 3$ billion in total economic activities (1). Fusarium yellows, a devastating disease of sugar beet, has become a serious problem for growers, especially in the Moorhead factory district in Minnesota $(10,19,32)$. Fusarium yellows was first described by Stewart in 1931 from sugar beet samples collected in Colorado (39). The causal pathogen initially was identified as Fusarium conglutinans var. betae D. Stewart and subsequently renamed $F$. oxysporum f. sp. betae W.C. Snyder \& H.N. Hansen (38). Six different Fusarium spp. (F. oxysporum, F. acuminatum Ellis \& Everh., F. avenaceum (Fr.) Sacc., F. solani (Mart.) Appel \& Wollenw., F. moniliforme J. Sheld., and F. graminearum Schwabe) have been reported to cause Fusarium yellows in the United States $(16,17,23,34)$. However, $F$. oxysporum f. sp. betae is considered to be the primary causal organism of Fusarium yellows (19). Rivera et al. (33) reported Fusarium sp. nov. also as a causal agent of yellowing decline in sugar beet. All of these Fusarium spp. cause similar symptoms on sugar beet (17).

Fusarium yellows is characterized by interveinal chlorosis and wilting as foliar symptoms, and vascular discoloration of the taproot with no external necrosis of the taproot or secondary roots (39). The disease symptoms first appear on the oldest leaf as interveinal chlorosis followed by necrosis (2). As the disease progresses, the pathogen may affect several whorls of leaves and the leaves may change from yellow to a brown necrotic color. Sometimes sectoring occurs, with only one side of the leaf along the midrib turning yellow, followed later by the entire leaf. Dampingoff and root rot occur on sugar beet but seed-producing beet may also be affected by stalk blight $(14,28)$. Fusarium yellows causes significant quantitative and qualitative yield losses due to reduced plant population, poor growth of plants, and increased impurities in the extracted juice $(19,20)$. As an added concern, Khan et al. (27)

Corresponding author: M. F. R. Khan, E-mail: mohamed.khan@ndsu.edu

Accepted for publication 23 March 2012.

http://dx.doi.org/10.1094/PDIS-10-11-0908-RE

(C) 2012 The American Phytopathological Society found increased respiration rate and reduced sucrose concentration of infected sugar beet roots compared with healthy roots after storage.

Fusarium yellows was reported in the Red River Valley of Minnesota and North Dakota during 2002 (26) and the disease was confirmed in 2005 (41). Growers of the American Crystal Sugar Company, the largest sugar beet cooperative in the United States, (25) are concerned about Fusarium yellows because the disease is now present in all their growing areas, especially the Moorhead Factory District. Rivera et al. (33) isolated F. oxysporum, F. graminearum, and Fusarium sp. nov. from sugar beet in fields located in the Moorhead Factory District in Minnesota. The objective of this study was to characterize both the pathogenicity and virulence of isolates of these three Fusarium spp. on a known Fusarium yellows-susceptible cultivar of sugar beet in the greenhouse. The pathogenicity and virulence of Fusarium sp. nov. likely has not been well studied or documented because most research has been done with $F$. oxysporum f. sp. betae.

\section{Materials and Methods}

Plant material and growing conditions. Fusarium yellows-susceptible 'Van der Have 46177' (31) was grown in the greenhouse. Seed were sown in cone-tainers $(3.8 \mathrm{~cm}$ in diameter by $21 \mathrm{~cm}$ deep; Stuewe \& Sons, Inc., Corvallis, OR) filled with Sunshine Mix 1 (Sun Gro Horticulture, Bellevue, WA) amended with $200 \mathrm{~g}$ of Osmocote 14-14-14 (Scotts Company, Marysville, OH) per 0.76 $\mathrm{m}^{3}$ of Sunshine Mix 1. Two seeds were sown in each cone-tainer at a depth of $2.2 \mathrm{~cm}$. Planting was done during the last week of November 2006 and mid-January 2007. Less vigorous plants were identified and removed 10 days after seedling emergence, leaving one plant per cone-tainer. Plants were grown in the greenhouse under fluorescent light set and maintained for a 16-h photoperiod and temperature set and maintained at $27 \pm 2^{\circ} \mathrm{C}$.

Isolates and inoculum preparation. Fusarium isolates were obtained from infected sugar beet from fields at Sabin and Georgetown, Clay County, and Fossum, Norman County in Minnesota in 2005. The Sabin and Georgetown sites were sugar beet screening nurseries and the Fossum site was a commercial field. Isolates were recovered and identified using standard procedures as described by Nelson et al. (30), including growth characteristics on potato dextrose agar (PDA), conidia morphology, and chlamydo- 
spore formation on carnation leaf agar. Isolates were stored on PDA in tubes at $-80^{\circ} \mathrm{C}$ until required (35). In this study, 18 isolates of $F$. oxysporum, 30 isolates of $F$. graminearum, and 50 isolates of Fusarium sp. nov. were used (Table 1). All isolates were transferred to freshly prepared half-strength (H)PDA (5) and grown for 10 days at 25 to $26^{\circ} \mathrm{C}$ with a 12-h photoperiod provided by fluorescent light. The plates were flooded with sterile distilled water and scraped with a sterile glass rod to obtain fungal mycelia and conidia. Conidia and mycelia were separated by filtering the suspension through cheesecloth. Conidia concentration was adjusted to 4 $\times 10^{4}$ macroconidia $\mathrm{ml}^{-1}$ using a hemocytometer. Two drops of polyoxyethylene-20-sorbitan monolaurate (Tween 20; Sigma-Aldrich, St. Louis) was added to $100 \mathrm{ml}$ of distilled water before autoclaving to help even distribution and adherence of inoculum.

Inoculation and disease assessment. Ninety-eight isolates were used to inoculate 38-day-old sugar beet plants at the eight-leaf growth stage. Plants were carefully removed from cone-tainers, and roots were washed with sterilized water and then dipped in a suspension of Fusarium conidia for $8 \mathrm{~min}$, as described by Hanson and Hill (17). The suspension was thoroughly shaken every minute for uniform distribution of conidia. Roots were dipped in sterile distilled water as a control. Plants were then transplanted immediately to cone-tainers filled with fresh Sunshine Mix 1, incubated in a growth chamber at $21 \pm 2^{\circ} \mathrm{C}$ for 2 days to reduce transplanting shock, and then transferred into a greenhouse at $27 \pm 2^{\circ} \mathrm{C}$. Natural light was supplemented with fluorescent light for a photoperiod of $16 \mathrm{~h}_{\text {day }}{ }^{-1}$.

To avoid confusion with transplanting shock, the oldest two leaves were removed 3 days after transplanting. Plants were carefully hand watered daily to avoid splashing of soil or water between different treatments. The experiment was designed as a randomized complete block with five replicates, where a single plant served as the experimental unit. The experiment was conducted in 2006 and repeated in 2007. A preliminary study (data not shown) indicated that some isolates did not cause vascular discoloration until 35 days after inoculation (DAI). As such, inoculated plants were evaluated for $60 \mathrm{DAI}$ in this study. Plants were independently rated twice weekly by the same rater for foliar symptoms using a disease severity rating scale of 0 to 4 similar to Hanson and Hill (17), with slight modifications, where $0=$ healthy plants with no symptoms; 1 = plants stunted and wilted, with few yellowed leaves ( 1 to $24 \%) ; 2=$ chlorosis and necrosis of leaves $(25$ to $59 \%) ; 3=$

Table 1. Days to first foliar symptoms, area under the disease progress curve (AUDPC), median disease severity (DS), relative treatment effect on disease severity $\left(P_{i j}\right)$, along with confidence intervals for relative treatments effect of 78 Fusarium isolates on the susceptible sugar beet 'Van der Have 46177 ' in greenhouse studies conducted in 2006 and 2007

\begin{tabular}{|c|c|c|c|c|c|c|}
\hline \multirow[b]{3}{*}{ Isolate number } & \multirow[b]{3}{*}{ Species } & \multirow[b]{3}{*}{ Days $^{v}$} & \multirow[b]{3}{*}{ AUDPC } & \multicolumn{3}{|c|}{ Disease severity $^{u}$} \\
\hline & & & & \multirow[b]{2}{*}{ Median } & \multicolumn{2}{|c|}{ Treatment relative effect } \\
\hline & & & & & $\left(\boldsymbol{P}_{i j}\right)^{\mathbf{w}}$ & $95 \% C^{x}$ \\
\hline 525 & Fusarium sp. nov. & $13 \mathrm{D}$ & $3,692 \mathrm{a}$ & 4 & 0.939 & $0.932-0.946$ \\
\hline 408 & Fusarium sp. nov. & $15 \mathrm{~B}-\mathrm{D}$ & $2,387 \mathrm{de}$ & 4 & 0.925 & $0.904-0.941$ \\
\hline 605 & Fusarium sp. nov. & $22 v-x$ & $2,498 \mathrm{de}$ & 4 & 0.925 & $0.904-0.941$ \\
\hline 581.52 & Fusarium sp. nov. & $19 y-A$ & $2,832 \mathrm{~cd}$ & 4 & 0.912 & $0.879-0.936$ \\
\hline 129 & Fusarium sp. nov. & $16 \mathrm{~A}-\mathrm{D}$ & $2,926 \mathrm{~b}-\mathrm{d}$ & 4 & 0.912 & $0.879-0.936$ \\
\hline $229 b$ & Fusarium sp. nov. & $14 \mathrm{CD}$ & $3,507 \mathrm{ab}$ & 4 & 0.913 & $0.874-0.940$ \\
\hline 581.508 & Fusarium sp. nov. & $18 \mathrm{y}-\mathrm{A}$ & $2,832 \mathrm{~cd}$ & 4 & 0.913 & $0.874-0.940$ \\
\hline 581.63 & Fusarium sp. nov. & $19 x-z$ & $2,610 \mathrm{c}-\mathrm{e}$ & 4 & 0.888 & $0.841-0.921$ \\
\hline 581.520 & Fusarium sp. nov. & $17 \mathrm{z}-\mathrm{C}$ & $3,132 \mathrm{a}-\mathrm{c}$ & 4 & 0.829 & $0.637-0.928$ \\
\hline 104 & Fusarium sp. nov. & $24 \mathrm{~s}-\mathrm{W}$ & 2,064 ef & 4 & 0.851 & $0.712-0.928$ \\
\hline 581.513 & Fusarium sp. nov. & $19 x-z$ & $2,220 \mathrm{ef}$ & 2 & 0.862 & $0.816-0.897$ \\
\hline 628 & Fusarium sp. nov. & $17 \mathrm{z}-\mathrm{C}$ & 2,181 ef & 2 & 0.848 & $0.812-0.877$ \\
\hline 630 & Fusarium sp. nov. & $15 \mathrm{~B}-\mathrm{D}$ & $1,635 \mathrm{fg}$ & 2 & 0.835 & $0.806-0.860$ \\
\hline 581.307 & Fusarium sp. nov. & $21 \mathrm{w}-\mathrm{y}$ & $1,374 \mathrm{gh}$ & 2 & 0.751 & $0.611-0.852$ \\
\hline 581.202 & Fusarium sp. nov. & $18 \mathrm{y}-\mathrm{B}$ & $1,137 \mathrm{~g}-\mathrm{i}$ & 2 & 0.689 & $0.550-0.801$ \\
\hline 210 & Fusarium sp. nov. & $27 \mathrm{~m}-\mathrm{r}$ & $788 \mathrm{i}-\mathrm{k}$ & 2 & 0.641 & $0.450-0.761$ \\
\hline 428 & Fusarium sp. nov. & $27 \mathrm{~m}-\mathrm{r}$ & $482 \mathrm{j}-\mathrm{m}$ & 2 & 0.641 & $0.5-0.761$ \\
\hline 518 & Fusarium sp. nov. & $27 \mathrm{~m}-\mathrm{s}$ & $788 \mathrm{i}-\mathrm{k}$ & 2 & 0.641 & $0.5-0.761$ \\
\hline 581.203 & Fusarium sp. nov. & $25 \mathrm{r}-\mathrm{V}$ & $228 \mathrm{k}-\mathrm{m}$ & 1 & 0.387 & $0.381-0.393$ \\
\hline 528.401 & Fusarium sp. nov. & $32 \mathrm{~d}-\mathrm{i}$ & $223 \mathrm{k}-\mathrm{m}$ & 1 & 0.387 & $0.381-0.393$ \\
\hline 581.21 & Fusarium sp. nov. & $33 \mathrm{~d}-\mathrm{g}$ & $179 \mathrm{~m}$ & 1 & 0.387 & $0.381-0.393$ \\
\hline 581.222 & Fusarium sp. nov. & $37 \mathrm{a}-\mathrm{c}$ & $179 \mathrm{~m}$ & 1 & 0.387 & $0.381-0.393$ \\
\hline 581.228 & Fusarium sp. nov. & $30 \mathrm{~g}-1$ & $214 \mathrm{k}-\mathrm{m}$ & 1 & 0.387 & $0.381-0.393$ \\
\hline 581.302 & Fusarium sp. nov. & $30 \mathrm{~h}-\mathrm{m}$ & $193 \mathrm{~m}$ & 1 & 0.387 & $0.381-0.393$ \\
\hline 581.506 & Fusarium sp. nov. & $25 \mathrm{r}-\mathrm{V}$ & $218 \mathrm{k}-\mathrm{m}$ & 1 & 0.387 & $0.381-0.393$ \\
\hline 581.516 & Fusarium sp. nov. & $281-q$ & $201 \mathrm{~lm}$ & 1 & 0.387 & $0.381-0.393$ \\
\hline 581.525 & Fusarium sp. nov. & $33 \mathrm{c}-\mathrm{f}$ & $296 \mathrm{k}-\mathrm{m}$ & 1 & 0.387 & $0.381-0.393$ \\
\hline 581.528 & Fusarium sp. nov. & $32 \mathrm{e}-\mathrm{j}$ & $330 \mathrm{k}-\mathrm{m}$ & 1 & 0.387 & $0.381-0.393$ \\
\hline 581.62 & Fusarium sp. nov. & $26 n-t$ & $193 \mathrm{~m}$ & 1 & 0.387 & $0.381-0.393$ \\
\hline 581.529 & Fusarium sp. nov. & $28 \mathrm{k}-\mathrm{p}$ & $386 \mathrm{k}-\mathrm{m}$ & 1 & 0.387 & $0.381-0.393$ \\
\hline 582.315 & Fusarium sp. nov. & $24 \mathrm{r}-\mathrm{V}$ & $219 \mathrm{k}-\mathrm{m}$ & 1 & 0.387 & $0.381-0.393$ \\
\hline 582.428 & Fusarium sp. nov. & $26 \mathrm{p}-\mathrm{u}$ & $210 \mathrm{k}-\mathrm{m}$ & 1 & 0.387 & $0.381-0.393$ \\
\hline 582.322 & Fusarium sp. nov. & $28 \mathrm{k}-\mathrm{p}$ & $349 \mathrm{k}-\mathrm{m}$ & 1 & 0.387 & $0.381-0.393$ \\
\hline $578.1 b$ & Fusarium sp. nov. & $27 \mathrm{~m}-\mathrm{s}$ & $166 \mathrm{~m}$ & 1 & 0.387 & $0.381-0.393$ \\
\hline $578.1 \mathrm{~B}$ & Fusarium sp. nov. & $25 \mathrm{p}-\mathrm{u}$ & $219 \mathrm{k}-\mathrm{m}$ & 1 & 0.387 & $0.381-0.393$ \\
\hline $578.1 \mathrm{c}$ & Fusarium sp. nov. & $25 \mathrm{p}-\mathrm{u}$ & $219 \mathrm{k}-\mathrm{m}$ & 1 & 0.387 & $0.381-0.393$ \\
\hline $578.1 d$ & Fusarium sp. nov. & $29 \mathrm{j}-\mathrm{o}$ & $219 \mathrm{k}-\mathrm{m}$ & 1 & 0.387 & $0.381-0.393$ \\
\hline & & & & & & (continued on next page) \\
\hline
\end{tabular}

\footnotetext{
u Symbol: - = data not calculated.

$\checkmark$ Average number of days from inoculation until the first symptoms were observed.

${ }^{\mathrm{w}}$ Estimated treatment relative effect.

${ }^{x}$ Upper-lower values of $95 \%$ confidence interval (CI) for treatment relative effect.

y No symptoms were observed at time the experiment was terminated.

${ }^{\mathrm{z}} \mathrm{LSD}=$ Fisher's protected least significant difference $(P=0.05)$.
} 
crown becoming dried and brown to black in color, leaves dying (60 to $89 \%)$; and $4=$ death of entire plant (90 to $100 \%)$. The isolates producing median disease severity values $<1,1$ to $1.9,2$ to 2.9 , and 3 to 4 were categorized as nonpathogenic, less virulent, moderately virulent, and highly virulent, respectively. The number of days required for appearance of first foliar symptom was recorded for each isolate. Isolations were made from root, crown, and petiole of at least three plants per treatment as described above to confirm pathogenicity.

Data analyses. Foliar disease severity ratings were converted to percentages using the midpoint rule, and the foliar severity value for each rating category was used to calculate area under the disease progress curve (AUDPC; 8). Median disease severity, days until first symptom detection, and AUDPC were used to characterize virulence of each isolate and species. Regression analysis was conducted to assess the relationship between days required to induce first symptoms and disease severity.

Isolates resulting in a median disease severity of 0 were considered nonpathogenic and were excluded from data analysis for characterization of pathogenic isolates. A homogeneous test was conducted for the two experiments based on the calculated $F$ values, as described by Gomez and Gomez (13), before combining the data from the two experiments. Analysis of variance, for the number of days required for appearance of first symptom, and AUDPC were performed using the Statistical Analysis System (SAS, version 9.1; SAS Institute Inc., Cary, NC). Fisher's protected least significance difference of means at $\alpha=0.05$ was calculated to compare treatments.

The Kruskal-Wallis test (3) was performed to determine whether the three Fusarium spp. differ from each other in terms of disease severity. The test was conducted using the MIXED procedure of SAS with the LSMEANS option (version 9.2; SAS Institute Inc.) $(3,36)$. Additionally, the estimated relative effects of treatments were compared using LD_CI macro (3).

\section{Results}

Plants inoculated with distilled water were healthy, with no Fusarium yellows symptoms. Among the 98 isolates tested, $80 \%$ (78 isolates) were pathogenic and the remaining 20\% (20 isolates) were nonpathogenic. In all, 92\% (46 of 50) of the Fusarium sp. nov. isolates, $83 \%$ ( 15 of 18 ) of the $F$. oxysporum isolates, and $57 \%$ (17 of 30) of the F. graminearum isolates were pathogenic based on the median value of the disease severity and relative effect of disease severity compared with the noninoculated control. Among the pathogenic isolates, $22 \%$ (10 of 46) of Fusarium sp. nov. and $7 \%$ ( 1 of 15 isolates) of $F$. oxysporum were highly virulent (sever-

Table 1. (continued from preceding page)

\begin{tabular}{|c|c|c|c|c|c|c|}
\hline \multirow[b]{3}{*}{ Isolate number } & \multirow[b]{3}{*}{ Species } & \multirow[b]{3}{*}{ Days $^{v}$} & \multirow[b]{3}{*}{ AUDPC } & \multicolumn{3}{|c|}{ Disease severity $^{\mathbf{u}}$} \\
\hline & & & & \multirow[b]{2}{*}{ Median } & \multicolumn{2}{|c|}{ Treatment relative effect } \\
\hline & & & & & $\left(P_{i j}\right)^{\mathbf{w}}$ & $95 \% \mathbf{C I}^{\mathrm{x}}$ \\
\hline $578.1 \mathrm{e}$ & Fusarium sp. nov. & $34 \mathrm{c}-\mathrm{f}$ & $149 \mathrm{~m}$ & 1 & 0.387 & $0.381-0.393$ \\
\hline $578.2 \mathrm{c}$ & Fusarium sp. nov. & $33 \mathrm{~d}-\mathrm{g}$ & $360 \mathrm{k}-\mathrm{m}$ & 1 & 0.387 & $0.381-0.393$ \\
\hline 113 & Fusarium sp. nov. & $25 q-v$ & $210 \mathrm{k}-\mathrm{m}$ & 1 & 0.387 & $0.381-0.393$ \\
\hline $229 a$ & Fusarium sp. nov. & $23 \mathrm{t}-\mathrm{w}$ & $210 \mathrm{k}-\mathrm{m}$ & 1 & 0.387 & $0.381-0.393$ \\
\hline 255 & Fusarium sp. nov. & $35 \mathrm{~b}-\mathrm{d}$ & $193 \mathrm{~m}$ & 1 & 0.387 & $0.381-0.393$ \\
\hline 423 & Fusarium sp. nov. & $31 \mathrm{e}-\mathrm{j}$ & $309 \mathrm{k}-\mathrm{m}$ & 1 & 0.387 & $0.381-0.393$ \\
\hline 506 & Fusarium sp. nov. & $38 \mathrm{a}$ & $201 \mathrm{~m}$ & 1 & 0.387 & $0.381-0.393$ \\
\hline 523 & Fusarium sp. nov. & $36 \mathrm{a}-\mathrm{c}$ & $295 \mathrm{k}-\mathrm{m}$ & 1 & 0.387 & $0.381-0.393$ \\
\hline $23 b$ & Fusarium sp. nov. & $36 \mathrm{a}-\mathrm{b}$ & $291 \mathrm{k}-\mathrm{m}$ & 1 & 0.387 & $0.381-0.393$ \\
\hline 218 & Fusarium oxysporum & $19 x-z$ & $2,832 \mathrm{~cd}$ & 4 & 0.913 & $0.874-0.941$ \\
\hline 581.121 & F. oxysporum & $15 \mathrm{~B}-\mathrm{D}$ & 2,051 ef & 2 & 0.812 & $0.694-0.891$ \\
\hline 581.202 & F. oxysporum & $22 v-x$ & $635 \mathrm{j}-1$ & 1 & 0.520 & $0.391-0.647$ \\
\hline 581.609 & F. oxysporum & $24 \mathrm{~s}-\mathrm{w}$ & $512 \mathrm{j}-\mathrm{m}$ & 1 & 0.472 & $0.366-0.581$ \\
\hline 581.205 & F. oxysporum & $33 \mathrm{~d}-\mathrm{g}$ & $175 \mathrm{~m}$ & 1 & 0.387 & $0.381-0.393$ \\
\hline $581.205 \mathrm{a}$ & F. oxysporum & $33 c-g$ & $140 \mathrm{~m}$ & 1 & 0.387 & $0.381-0.393$ \\
\hline $581.225 \mathrm{a}$ & F. oxysporum & $23 \mathrm{u}-\mathrm{w}$ & $254 \mathrm{k}-\mathrm{m}$ & 1 & 0.387 & $0.381-0.393$ \\
\hline 581.318 & F. oxysporum & $34 \mathrm{c}-\mathrm{e}$ & $140 \mathrm{~m}$ & 1 & 0.387 & $0.381-0.393$ \\
\hline 581.321 & F. oxysporum & $28 \mathrm{k}-\mathrm{p}$ & $184 \mathrm{~m}$ & 1 & 0.387 & $0.381-0.393$ \\
\hline $581.415 b$ & F. oxysporum & $24 \mathrm{~s}-\mathrm{w}$ & $131 \mathrm{~m}$ & 1 & 0.387 & $0.381-0.393$ \\
\hline 581.615 & F. oxysporum & $31 \mathrm{f}-\mathrm{k}$ & $210 \mathrm{k}-\mathrm{m}$ & 1 & 0.387 & $0.381-0.393$ \\
\hline $578.2 \mathrm{a}$ & F. oxysporum & $26 \mathrm{o}-\mathrm{u}$ & $184 \mathrm{~m}$ & 1 & 0.387 & $0.381-0.393$ \\
\hline $578.2 b$ & F. oxysporum & $25 q-v$ & $219 \mathrm{k}-\mathrm{m}$ & 1 & 0.387 & $0.381-0.393$ \\
\hline $578.3 d$ & F. oxysporum & $25 \mathrm{r}-\mathrm{v}$ & $236 \mathrm{k}-\mathrm{m}$ & 1 & 0.387 & $0.381-0.393$ \\
\hline 609 & F. oxysporum & $32 e-j$ & $263 \mathrm{k}-\mathrm{m}$ & 1 & 0.387 & $0.381-0.393$ \\
\hline 581.304 & F. graminearum & $30 \mathrm{~h}-\mathrm{m}$ & $201 \mathrm{~lm}$ & 1 & 0.387 & $0.381-0.393$ \\
\hline 581.403 & F. graminearum & $25 \mathrm{p}-\mathrm{u}$ & $123 \mathrm{~m}$ & 1 & 0.387 & $0.381-0.393$ \\
\hline 581.404 & F. graminearum & $26 \mathrm{p}-\mathrm{u}$ & $158 \mathrm{~m}$ & 1 & 0.387 & $0.381-0.393$ \\
\hline 581.523 & F. graminearum & $32 \mathrm{e}-\mathrm{j}$ & $369 \mathrm{k}-\mathrm{m}$ & 1 & 0.387 & $0.381-0.393$ \\
\hline 581.628 & $F$. graminearum & $32 \mathrm{e}-\mathrm{j}$ & $219 \mathrm{k}-\mathrm{m}$ & 1 & 0.387 & $0.381-0.393$ \\
\hline 581.101 & F. graminearum & $17 z-C$ & $1,025 \mathrm{~h}-\mathrm{j}$ & 1 & 0.556 & $0.422-0.683$ \\
\hline $578.2 c$ & F. graminearum & $281-q$ & $149 \mathrm{~m}$ & 1 & 0.387 & $0.381-0.393$ \\
\hline $578.2 \mathrm{e}$ & F. graminearum & $23 \mathrm{u}-\mathrm{w}$ & $236 \mathrm{k}-\mathrm{m}$ & 1 & 0.387 & $0.381-0.393$ \\
\hline $578.2 f$ & F. graminearum & $23 \mathrm{t}-\mathrm{w}$ & $175 \mathrm{~m}$ & 1 & 0.387 & $0.381-0.393$ \\
\hline $578.5 b$ & F. graminearum & $32 \mathrm{~d}-\mathrm{h}$ & $369 \mathrm{k}-\mathrm{m}$ & 1 & 0.387 & $0.381-0.393$ \\
\hline $578.5 c$ & F. graminearum & 29 i-n & $219 \mathrm{k}-\mathrm{m}$ & 1 & 0.387 & $0.381-0.393$ \\
\hline $578.5 d$ & F. graminearum & $27 \mathrm{~m}-\mathrm{r}$ & $193 \mathrm{~m}$ & 1 & 0.387 & $0.381-0.393$ \\
\hline $578.5 \mathrm{D}$ & F. graminearum & $31 \mathrm{f}-\mathrm{k}$ & $386 \mathrm{k}-\mathrm{m}$ & 1 & 0.387 & $0.381-0.393$ \\
\hline 202 & F. graminearum & $31 \mathrm{f}-\mathrm{k}$ & $386 \mathrm{k}-\mathrm{m}$ & 1 & 0.387 & $0.381-0.393$ \\
\hline $578.1 \mathrm{a}$ & F. graminearum & $29 \mathrm{~h}-\mathrm{m}$ & $325 \mathrm{k}-\mathrm{m}$ & 1 & 0.387 & $0.381-0.393$ \\
\hline $578.2 \mathrm{e}$ & F. graminearum & $29 \mathrm{~h}-\mathrm{m}$ & $175 \mathrm{~m}$ & 1 & 0.387 & $0.381-0.393$ \\
\hline $47 / 48$ & F. graminearum & $38 \mathrm{ab}$ & $295 \mathrm{k}-\mathrm{m}$ & 1 & 0.387 & $0.381-0.393$ \\
\hline Noninoculated check ${ }^{\mathrm{y}}$ & $\ldots$ & $\ldots$ & 0 & 0 & 0.000 & $0.000-0.000$ \\
\hline Overall mean & $\ldots$ & 26.3 & 754 & 1.5 & - & - \\
\hline$P>F$ & $\ldots$ & $<0.01$ & $<0.01$ & $<0.05$ & $<0.05$ & 0.05 \\
\hline $\mathrm{LSD}^{\mathrm{z}}$ & $\ldots$ & 3.1 & 585 & - & - & - \\
\hline
\end{tabular}


ity rating of 3 to 4; Fig. 1; Table 1).Three of the most virulent isolates of Fusarium sp. nov. caused death of the plants. In total, $6 \%$ of F. oxysporum and $16 \%$ of Fusarium sp. nov. were moderately virulent (severity rating of 2 to 2.9 ; Fig. 1 ). Of the 78 pathogenic isolates, $74 \%$ (58 isolates) of the isolates were less virulent and consisted of $48 \%$ (28 isolates) Fusarium sp. nov., $22 \%$ (13 isolates) $F$. oxysporum, and $29 \%$ (17 isolates) $F$. graminearum (Fig. 1).

An $F$ test for the homogeneity of residual mean squares from the individual analyses of variance was not significant for measurements of disease severity $(P=0.08)$, days required for the first symptom to appear $(P=0.28)$, and AUDPC $(P=0.33)$. Analyses of combining data from the two experiments showed that there was no significant difference in 2006 and 2007 for disease severity $(P=$ $0.66)$, days required for the first symptoms to appear $(P=0.87)$, and AUDPC $(P=0.98)$. The interaction between year and isolate was not significant for disease severity $(P=0.86)$ and AUDPC $(P$ $=0.97)$ but was statistically significant $(P<0.01)$ for the number of days required to induce the first disease symptoms. However, the interaction component accounted for as little as $5.6 \%$ of the total variance for the number of days required for the first disease symptom to appear. All these indicated that measurements of Fusarium disease metrics using bare-root inoculation and under controlled greenhouse conditions were reproducible and that the ranking of different isolates in pathogenicity and virulence should remain the same regardless of when the evaluation programs are carried out.

The disease severity, AUDPC, and days required for appearance of first symptom were significantly different $(P<0.05)$ among pathogenic isolates considered pathogenic, those which caused disease severities $\geq 1$ (Table 1). Generally, more-virulent isolates induced first foliar symptoms earlier compared with less-virulent isolates (Table 1). The regression analysis of combined observations from three different Fusarium spp. showed that days required after inoculation for first symptoms accounted for $64 \%$ variability in disease severity $\left(R^{2}=0.64, P<0.01\right)$ between number of days required for first symptom development and disease severity (Fig. 2 ). The number of days required to induce the first symptom was 13 to 23 for the highly virulent isolates, 15 to 21 for the moderately virulent isolates, and 17 to 38 for the less virulent isolates. Isolate 525 (a Fusarium sp. nov.) was the most virulent and induced foliar yellowing symptoms at 13 DAI and death of entire plants by 32 DAI, and also resulted in the highest AUDPC and the highest vascular discoloration of roots. AUDPC caused by pathogenic

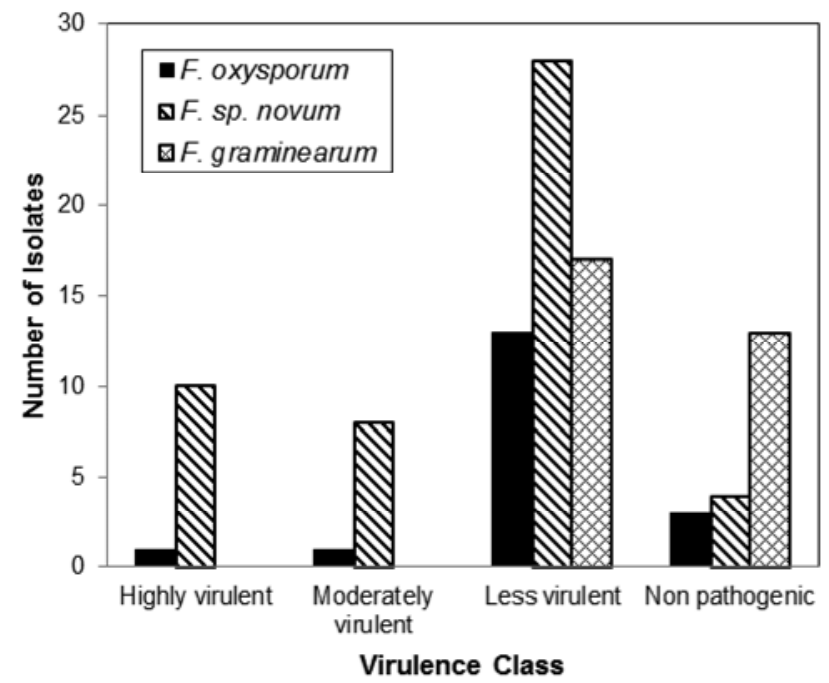

Fig. 1. Frequency distribution of isolates from three Fusarium spp. according to their virulence on sugar beet in greenhouse assays. Severity classes are based on a 0-to-4 rating scale, where $0=$ no symptoms. Classes are median ratings for five plants; 0 to $0.9=$ nonpathogenic, median ratings 1 to $1.9=$ less virulent, median ratings 2 to $2.9=$ moderately virulent, and median ratings 3 to $4=$ highly virulent. isolates varied from 123 to 3,692 (Table 1). Cultures of Fusarium spp. recovered from inoculated plants were identical to those used at inoculation. $F$. oxysporum and $F$. graminearum isolates were reisolated from root and crown, whereas Fusarium sp. nov. was reisolated from root, crown, and petiole of infected plants inoculated with $F$. oxysporum, $F$. graminearum, and $F$. sp. nov., respectively.

\section{Discussion}

Shaner et al. (37) defined concepts of pathogenicity and virulence in several ways. In this study, Fusarium spp. inoculated at the eight-leaf growth stage which were able to induce disease symptoms (median disease severity $\geq 1$ ) different from the noninoculated check plants (median disease severity $=0$ ) were considered pathogenic. Virulence was considered the variation in the degree of disease severity caused by each Fusarium isolate. This study showed distinct variation in pathogenicity and virulence among three Fusarium spp. and among the isolates within each species found and collected from Minnesota sugar beet fields. Interestingly, isolates of a Fusarium sp. nov. showed higher frequency of pathogenicity and higher degree of virulence and, typically, induced disease symptoms earlier than the isolates of $F$. oxysporum and $F$. graminearum (Fig. 1). This would suggest that sugar beet fields with Fusarium sp. nov. will be more likely to have more severe disease than fields with $F$. oxysporum and $F$. graminearum under similar favorable environmental conditions. Moreover, Fusarium sp. nov. has been reported only from the Red River Valley of North Dakota and Minnesota (33). Regression analysis showed there was a relationship $\left(R^{2}=0.64, P<0.01\right.$; Fig. 2$)$ between number of days required for symptom development and disease severity. In most instances, the more-virulent isolates of each species induced foliar symptoms earlier than less-virulent isolates (Table 1).

In all, $80 \%$ of the 98 isolates collected and identified from three Fusarium spp. in Minnesota in 2005 were pathogenic to sugar beet. The frequency of pathogenic isolates of Fusarium sp. nov. was higher $(92 \%)$ than F. oxysporum (83\%) and F. graminearum $(57 \%)$. Associations of multiple Fusarium spp. on Fusarium yellows-infected sugar beet have been reported; however, the frequency of pathogenic isolates and degree of virulence among the isolates varied in the different studies. High frequency $(82.5 \%)$ of pathogenic isolates of $F$. oxysporum was reported from Texas (21). In

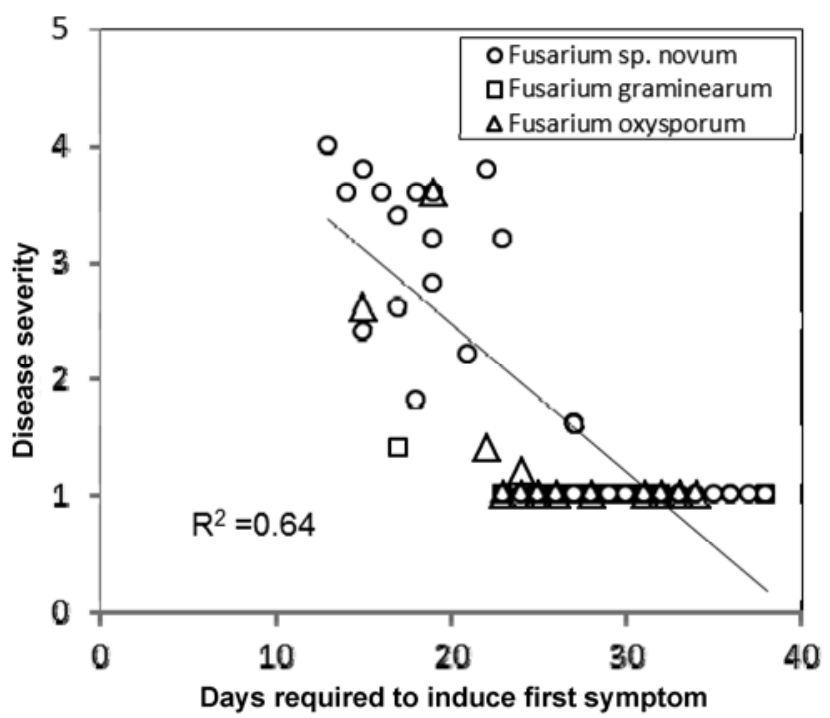

Fig. 2. Relationship between disease severity and days required after inoculation for the first symptoms to appear in greenhouse assays with three different Fusarium spp. comprising 78 pathogenic isolates. Regression analysis showed that days required after inoculation for first symptoms to appear had a negative relationship $\left(R^{2}=0.64 ; P<0.01\right)$ with disease severity. Each data point is the average of ten observations. 
contrast, Hanson and Hill (17) and Ruppel (33) found that 21 and $25 \%$ of their isolates, respectively, obtained from a different geographic area were pathogenic. The higher frequency of pathogenic isolates found in this study suggests that these isolates were probably more competitive and virulent. Each of the studies-Harveson and Rush (21,22), Hanson and Hill (17), Ruppel (34), and oursused different Fusarium spp.-susceptible cultivars of sugar beet with different inherent levels of resistance to Fusarium yellows, which will also influence pathogenicity of the isolates (18). We do not know why Fusarium yellows complex, which was not considered a major problem for many years, suddenly began to infect numerous sugar beet fields in North Dakota and Minnesota starting around 2002. Around that time, Rhizomania, caused by Beet necrotic yellow vein virus and vectored by Polymyxae betae had become widespread and was starting to cause significant yield losses, and growers were adopting Rhizomania-resistant cultivars (19). It was observed that cultivar Van der Have 46177, a specialty cultivar approved because of good partial resistance to both Rhizomania and Aphanomyces cochlioides, which causes Aphanomyces root rot, was the most susceptible cultivar to Fusarium spp. in field and greenhouse studies $(4,31)$. It was possible that some of the newer Rhizomania-resistant cultivars had less resistance to Fusarium spp.

Another possible reason for more Fusarium yellows complex in the Moorhead Factory District may be the presence of Fusarium sp. nov., which can be very virulent and occurred more frequently than $F$. oxysporum. Several researchers have reported new or different additional Fusarium spp. that cause diseases in other crops, including asparagus and chickpea $(9,24)$ Similar to our study, Jimenez-Fernandez et al. (24) reported $F$. redolens, a new causal agent of Fusarium yellows in chickpea, which resulted in foliar symptoms similar to those of $F$. oxysporum f. sp. ciceris, previously considered as the principal causal agent of the disease on chickpea.

All the pathogenic isolates from the three Fusarium spp. showed similar foliar symptoms, including leaf yellowing (half- to full-leaf yellowing), interveinal yellowing, chlorosis, and necrosis of leaves, and most also induced vascular discoloration of the tap root and secondary roots. However, the more-virulent isolates generally resulted in more vascular discoloration than the less-virulent isolates. As such, F. graminearum isolates induced the lowest vascular discoloration and half-leaf yellowing. Because none of the roots had external symptoms, this will imply that the Fusarium disease present in Minnesota and North Dakota is distinctly different from the Fusarium root rot in Texas, where root tips are distinctly discolored and rotted (20). In some roots, cross sections showed decay of the entire central stele $(0.5$ to $1.0 \mathrm{~cm}$ in diameter) while most of the outer stele was healthy. Isolates that caused yellowing, chlorosis, and necrosis on foliar parts would adversely impact plant health and photosynthetic area. As such, infected sugar beet plants in fields will be expected to have reduced growth and yield potential (11).

In Minnesota and North Dakota, sugar beet is grown in rotation with wheat (spring, winter, and durum) barley, soybean, and corn (40), with predominantly wheat, barley, or corn being the preceding crop. $F$. graminearum is the primary Fusarium pathogen of wheat in Minnesota and North Dakota (29). Isolates of $F$. graminearum collected from wheat and sugar beet were genetically similar and belong to the same clade of $F$. graminearum complex (6) and were able to cause disease on both hosts alternatively (7). Although $F$. graminearum was shown to be pathogenic in this study, all isolates were less pathogenic, which suggests that it may not be a damaging pathogen of the sugar beet plant under the conditions evaluated. However, because $F$. graminearum causes dry rot on injured sugar beet root (12), it could pose problems to injured roots during the storage period.

The pathogen was reisolated from the root and crown of all inoculated seedlings with both pathogenic and nonpathogenic isolates. Interestingly, pathogenic isolates of Fusarium sp. nov. were also reisolated from the petiole, probably because it grew quickly and moved through the vascular system faster than other species. The isolation of Fusarium spp. from the inner core of inoculated symptomless roots is consistent with previous studies $(17,34)$. Reisolation of Fusarium spp. from symptomless roots suggests that the fungus can survive in plants without stimulating a pathogenic response.

Previously, severities of Fusarium yellows of sugar beet were evaluated up to 42 DAI for pathogenicity and virulence studies $(16,17,34,41)$. Our preliminary study showed that some isolates initiated symptoms from 30 to 38 DAI. In this study, plants that developed yellowing symptoms of oldest leaves 30 to 38 DAI looked healthy later, when the initial infected leaves died. Isolates that caused initial yellowing symptoms to appear 25 and more DAI were all less virulent. Therefore, there would have been no differences in the number of days required to induce first symptoms or the disease severity of the isolates if the test was concluded 42 DAI. As such, future pathogenicity evaluations should be no longer than 42 DAI because the rankings of pathogenicity and virulence will not change.

In conclusion, isolates of three Fusarium spp. were characterized and evaluated for pathogenicity and virulence on a susceptible sugar beet host. Fusarium sp. nov. was the most commonly pathogenic, followed by $F$. oxysporum and $F$. graminearum. All of the $F$. graminearum isolates were less virulent and may not cause serious damage to sugar beet. Seed companies that develop Fusarium spp.resistant cultivars for Minnesota and North Dakota should include both $F$. oxysporum and Fusarium sp. nov. when screening cultivars and conduct field studies in areas where both $F$. oxysporum and Fusarium sp. nov. are present.

\section{Acknowledgments}

We thank R. R. Burlakoti for reviewing the manuscript and technical help, the North Dakota State Board of Agricultural Research and Education for partial funding of this project, and the Minnesota and North Dakota Sugarbeet Research and Education Board for supporting this project.

\section{Literature Cited}

1. Bangsund, D. A., and Leistritz, F. L. 2004. Economic contribution of the sugar beet industry in Minnesota, North Dakota and Montana. Agribusiness Appl. Econ. Rep. No. 532. North Dakota State University, Fargo.

2. Bockstahler, H. W. 1940. Resistance to Fusarium yellows in sugar beets. Pages 191-198 in: Proc. Am. Soc. Sugar Beet Technol. Colorado.

3. Brunner, E., and Puri, M. L. 2001. Nonparametric methods in factorial designs. Stat. Pap. 42:1-52.

4. Burlakoti, P. 2007. Fusarium species associated with sugar beet grown in the Red River Valley: pathogenicity, cultivar response, and baseline sensitivity to fungicides. M.S. Thesis, North Dakota State University, Fargo.

5. Burlakoti, P., Rivera, V. V., Burlakoti, R. R., Nelson, R., Adhikari, T. B., Secor, G. A., and Khan, M. F. R. 2010. Baseline sensitivity of Fusarium species associated with Fusarium diseases to metconazole, triticonazole, and thiabendazole fungicides. J. Sugar Beet Res. 47:23-34.

6. Burlakoti, R. R., Ali, S., Secor, G. A., Neate, S. M., McMullen, M. P., and Adhikari, T. B. 2008. Genetic relationships among populations of Gibberella zeae from barley, wheat, potato and sugar beet in the upper Midwest of the United States. Phytopathology 98:969-976.

7. Burlakoti, R. R., Estrada, R., Jr., Rivera, V. V., Boddeda, A., Secor, G. A., and Adhikari, T. B. 2007. Real-time PCR quantification and mycotoxin production of Fusarium graminearum in wheat inoculated with isolates collected from potato, sugar beet, and wheat. Phytopathology 97:835-841.

8. Campbell, C. L., and Madden, L. V. 2006. Introduction to Plant Disease Epidemiology. John Wiley and Sons, New York.

9. Corpus-Hervias, C., Melero-Vara, J. M., Molinero-Ruiz, M. L., ZureraMunoz, C., and Basallote-Ureba, M. J. 2006. Characterization of isolates of Fusarium spp. obtained from asparagus in Spain. Plant Dis. 90:1441-1451.

10. Duffus, J. E., and Ruppel, E. G. 1993. Diseases. Pages 346-427 in: The Sugar Beet Crop-Science into Practice. D. A. Cooke and R. K. Scott, eds. Chapman and Hall, London.

11. Elliott, M. C., and Weston, G. D. 1993. Biology and physiology of the sugar beet plant. Pages 37-66 in: The Sugar Beet Crop: Science into practice. D. A. Cooke and R. K. Scott, eds. Chapman and Hall, London.

12. Estrada, R., Jr., Gudmestad, N., Rivera, V. V., and Secor, G. A. 2010 Fusarium graminearum as a dry rot pathogen of potato in the USA: prevalence, comparison of host isolate aggressiveness and factors affecting etiology. Plant Pathol. 59:1114-1120.

13. Gomez, K. A., and Gomez, A. A. 1984. Statistical Procedures for Agricultural Research, 2nd ed. John-Wiley \& Sons, New York.

14. Gross, D. C., and Leach, L. D. 1973. Stalk blight of sugarbeet seed crops caused by Fusarium oxysporum f. sp. betae. (Abstr.) Phytopathology 63:1216. 
15. Haley, S., and McConnell, M. 2011. Sugar and sweeteners outlook. In: Electronic outlook report from the economic research service. http://www.ers.usda.gov/publications/sss/2011/01Jan/SSSM269.pdf

16. Hanson, L. E. 2006. Fusarium yellowing of sugar beet caused by Fusarium graminearum from Minnesota and Wyoming. Plant Dis. 90:686.

17. Hanson, L. E., and Hill, A. L. 2004. Fusarium species causing Fusarium yellows of sugar beet. J. Sugar Beet Res. 41:163-178.

18. Hanson, L. E., Hill, A. L., Jacobsen, B. J., and Panella, L. 2009. Variable response of different sugar beet lines with Fusarium oxysporum f. sp. betae from the United States. J. Sugar Beet Res. 46:11-26.

19. Hanson, L. E, and Jacobsen, B. J. 2009. Fusarium yellows. Pages 28-29 in: Compendium of Beet Diseases and Pests, 2nd ed. R. M. Harveson, L. E. Hanson, and G. L. Hein, eds. American Phytopathological Society, St. Paul, MN.

20. Harveson, R. M. 2009. Fusarium root rot. Pages 28-29 in: Compendium of Beet Diseases and Pests, 2nd ed. R. M. Harveson, L. E. Hanson, and G. L. Hein, eds. American Phytopathological Society, St. Paul, MN.

21. Harveson, R. M., and Rush, C. M. 1997. Genetic variation among Fusarium oxysporum isolates from sugar beet as determined by vegetative compatibility. Plant Dis. 81:85-88.

22. Harveson, R. M., and Rush, C. M. 1998. Characterization of Fusarium root rot isolates from sugar beet by growth and virulence at different temperatures and irrigation regimes. Plant Dis. 82:1039-1042.

23. Hill, A. L., Reeves, P. A., Larson, R. L., Fenwick, A. L., Hanson, L. E., and Panella, L. 2011. Genetic variability among isolates of Fusarium oxysporum from sugar beet. Plant Pathol. 60:496-505.

24. Jiménez-Fernández, D., Navas-Cortés, J. A., Montes-Borrego, M., JiménezDíaz, R. M., and Landa, B. B. 2011. Molecular and pathogenic characterization of Fusarium redolens, a new causal agent of Fusarium yellows in chickpea. Plant Dis. 95:860-870.

25. Khan, M. F. R. 2008. Successful collaboration between industry and universities in the US beet sugar industry. Int. Sugar J. 110:218-220.

26. Khan, M. F. R., Bradley, C. A., and Windels, C. E. 2003. Fusarium yellows of sugar beet. Univ. Minn. Ext. Serv. N. D. State Univ. Ext. Serv. PP-1247.

27. Khan, M. F. R., Campbell, L. G., and Nelson, R. 2005. Effect of Fusarium root rot on sugar beet in Minnesota, USA. In: Proc. 68th IIRB Congr. MECC, Maastricht, The Netherlands.
28. McDonald, J. D., and Leach, L. D. 1976. Evidence for an expanded host range of Fusarium oxysporum f. sp. betae. Phytopathology 66:822-827.

29. McMullen, M., Jones, R., and Gallenberg, D. 1997. Scab of wheat and barley: a re-emerging disease of devastating impact. Plant Dis. 81:13401348

30. Nelson, P. E., Toussoun, T. A., and Marasas, W. F. O. 1983. Fusarium Species: An Illustrated Manual for Identification. Pennsylvania State University Press, University Park.

31. Niehaus, W. S. 2006. Results of American Crystal's 2005 Official Coded Variety trials. 2005 Sugar Beet Res. Ext. Rep. 36:331-333.

32. Panella, L., and Lewellen, R. T. 2005. Objectives of sugar beet breeding. Pages 53-167 in: Genetics and Breeding of Sugar Beet. E. Biancardi, L. G. Campbell, G. N. Skaracis, and M. de Biaggi, eds. Science Publishers, Inc., New Hampshire.

33. Rivera, V. V., Rengifo, J., Khan, M., Geiser, D. M., Mansfield, M., an Secor, G. 2008. First report of a novel Fusarium species causing sugar beet yellows in Minnesota. Plant Dis. 92:1589.

34. Ruppel, E. G. 1991. Pathogenicity of Fusarium spp. from diseased sugar beets and variation among sugar beet isolates of $F$. oxysporum. Plant Dis. 75:486-489.

35. Secor, G., and Rivera, V. V. 2005. Identification of Fusarium species isolated from diseased sugar beet in MN and ND. 2004 Sugar Beet Res. Ext Rep. 36:262-264.

36. Shah, D. A., and Madden, L. V. 2004. Nonparametric analysis of ordinal data in designed factorial experiments. Phytopathology 94:33-43.

37. Shaner, G., Stromberg, E. L., Lacy, G. H., Barker, K. R., and Pirone, T. P. 1992. Nomenclature and concepts of pathogenicity and virulence. Annu. Rev. Phytopathol. 30:47-66.

38. Snyder, W. C., and Hansen, H. N. 1940. The species concept in Fusarium. Am. J. Bot. 27:64-67.

39. Stewart, D. 1931. Sugar-beet yellows caused by Fusarium conglutinans var. betae. Phytopathology 21:59-70.

40. USDA-NASS. 2003. Agricultural statistics data base (quick stats). USDANASS, Washington, DC. www.nass.usda.gov

41. Windels, C. E., Brantner, J. R., Bradley, C. A., and Khan, M. F. R. 2005 First report of Fusarium oxysporum causing yellows on sugar beet in the Red River Valley of Minnesota and North Dakota. Plant Dis. 89:341. 